\title{
ABCB4 wt Allele
}

National Cancer Institute

\section{Source}

National Cancer Institute. ABCB4 wt Allele. NCI Thesaurus. Code C123863.

Human ABCB4 wild-type allele is located in the vicinity of 7q21.1 and is approximately 79 $\mathrm{kb}$ in length. This allele, which encodes multidrug resistance protein 3 , plays a role in the intramembrane transport of phosphatidylcholine and the export of organic anions and drugs across the plasma membrane. Mutation of the gene is associated with progressive familial intrahepatic cholestasis 2 , intrahepatic cholestasis of pregnancy 3 and gall bladder disease 3 . 